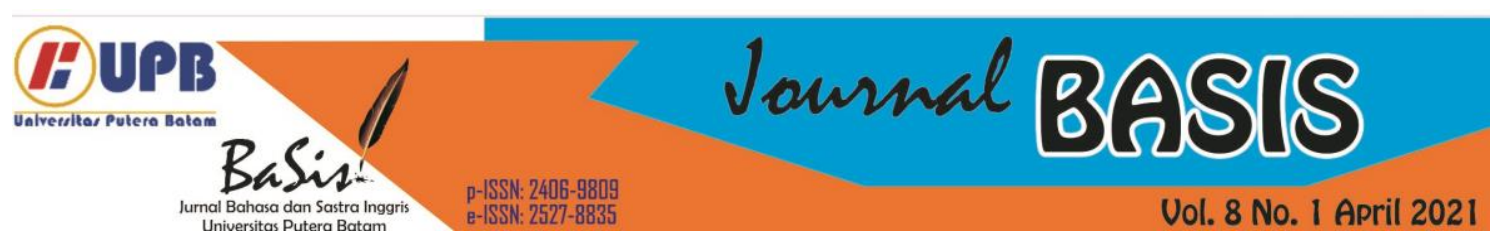

\title{
USING OUTLINING STRATEGY IN ESSAY WRITING FOR ELT STUDENTS'
}

\author{
Siti Fatimah Al Islamiah ${ }^{1}$ \\ STKIP PGRI Sidoarjo, Indonesia \\ mia7unior@gmail.com ${ }^{1}$ \\ Dina Merris Maya Sari² \\ STKIP PGRI Sidoarjo ${ }^{1}$, Indonesia \\ merrisdina01@gmail.com ${ }^{2}$
}

\begin{abstract}
This study discusses outlining strategy applied in the ELT students' essay writing class in an English Education Program STKIP PGRI Sidoarjo which included 10 students in 2019. The instruments used in this study were checklist observation and questionnaires. The data technique used is qualitative data, where the data will be described. The first research instrument, the researcher used a checklist observation form for implementation assessment by observing the class writing essays and participating in learning activities from beginning to end whose data was described in a table with a tick, the results showed that many activities were carried out by students in the classroom to improve their abilities in writing essays through an outlining strategy. The next instrument is a questionnaire for response assessment, the researcher asks for data from ELT students via a google form containing 15 yes or no questions. The results of the questionnaire showed that $90 \%$ of students answered yes, and $10 \%$ of students answered no. The results showed that the implementation and response of students were very positive and good during the learning activities to write essays using the outlining strategies of ELT students.
\end{abstract}

Keywords : Essay Writing, Outlining Strategy, ELT Students'

\section{INTRODUCTION}

Writing is lowering, imitating or depicting what is in our minds into a symbol, word, sentence that describes a language that is understood by someone, so that other people can read the symbol, so that they can understand the language and the description of the symbol. Writing is called a process of thinking and expressing that thought in the form of an essay. writing can give birth to feelings or thoughts with writing. Writing is one of the English language skills and also is an essential aspect of interaction on language teaching beside reading and speaking. The purpose of writing is to share about the feelings, thoughts, and ideas in written form to the readers (Urrutia L. J, 2011)

Students are certainly familiar with writing essays. An essay is an essay that discusses a problem from the author's point of view. In the essay contains opinions, views or personal expressions of the author regarding something that is happening or taking place in society. An essay can also be interpreted aswriting consisting of several paragraphs contains a topic from a point of view author. The difference with paragraphs, essays discussdeeper topics that require several paragraphs to 
discuss the topics raised (Wijayanti, 2011). As writing is more personal in nature, many essays are presented in a less formal style, not tied to a strict writing structure and served in fresh language. Essays many of us have encountered in various mass media, for example newspapers, magazines and newsletters (Nurhadi, 2017).

Types of essays can be scientific and essays literary essay. Scientific essays are more objective, while literary essays are more subjective. Scientific essays can be scientific articles, short papers, or short compositions. These essay forms are classified as short essays, while long essays can be in the form of theses, theses, dissertations, and others (Dalman, 2015). While literary essays emphasize the author's appreciation of the subject he will discuss. This is what allows each person's impression to be different. So, based on the explanation above, it can be said that an essay is a form of work write a description of the author's opinion about a particular topic. Based on this, there must be many students who have difficulty writing essays. and one way to be able to write an essay well is to make an outline strategy as the second step after determining the title in writing an essay.

The strategy of making an outline is a strategy by writing that contains an outline part of an essay so that the organized ideas become directed and systematic. The function of making an outline is as a control tool, a guide, a handle in writing to direct the writer so that the writing can be arranged in an orderly, structured manner, so that writing does not experience repetition, and writing can be coherent. Outline makes it easier for students to develop and improve ideas in essay writing that will be made. Maybe many students who before write an essays directly written with the ideas in mind without needing to think that writing an outline is not important. Even though things like that will actually make it difficult for students. The ideas they write in the essay will become unfocused without an outline.

With an outline, students know better what they want to discuss, so they don't get confused halfway in writing. An outline can be written in accordance with the structure of the essay, namely the title, introduction, content of the essay, and conclusion. Title is the core of the topic of discussion to be written, introduction is something that includes an overview of the topic of writing that discusses what and why writing needs to be written, content is the main description of the writing that will be discussed. and the conclusion is the result of the discussion in the writing that is made. In the outline must contain a draft outline of the main points of the an essays. So that later afterwards, the idea of writing can be deciphered properly and logically.

As an ELT student must be able to write essays. The ability to write essays is an important skill for ELT students. Through essays, students can express brilliant and positive ideas, ideas, and thoughts through writing essays and make positive contributions to problems that occur in society. But usually many students are still confused about decomposing writing into an essay because they think it is a difficult, complicated, and boring thing. Other reasons are the fear of being wrong, it is difficult to determine ideas, it is difficult to choose words, and it is difficult to compose words.

In this case, students need to learn to write an outline first so that the writing that will be compiled becomes clearer and more focused. A strategy is a plan, action or activity carried out by a 
person to achieve certain predetermined goals or objectives. In this study, there is the aim of the researcher, namely to facilitate ELT students in writing essays through an outline strategy in order to produce neat, good writing, still at the core of writing, directed and clear. The outline strategy is very important to train ELT students who will make essays so they not confused on the way when writing essays. The outline will guide students when writing an essay, so that the contents of the essay not deviate far from the main title.

Based on this explanation, the writer wants to write a research entitled "Using Outlining Strategy in Essay Writing for ELT Students". And this research was conducted at STKIP PGRI Sidoarjo with research subjects from class 2019 A students, totaling 10 students. The researcher choose ELT students to be the subject of this study because the author was an ELT student who was also studying at STKIP PGRI Sidoarjo.

\section{LITERATURE REVIEW}

\subsection{Writing Performance Situation} and Problem in Indonesia

According to a survey made by the United Nations Educational, Scientific and Cultural Organization (UNESCO), in 2012 stated that reading interest in Indonesia is valued at 0.001 , it's means that only 1 in 1000 people have a penchant for reading, based on this, Indonesia has been named a country with the lowest interest in reading in ASEAN. From the interview of the head Bandung Language Center, Abdul Khak told to kompas.com that the tradition of writing in Indonesia is much lower than the tradition of reading because it was initially due to low interest in reading which affected it. Reading and writing activities influence each other. We need to read to get references from the reading that we read for the next part of the reading we can write to become an essay.

This low reading interest affects the writing of scientific papers or essays that ELT students will make in higher education for the courses that will be taken, how can ELT students be able to write essays if the material studies in essay making are not understood due to lack of reading reading from knowledge sources other references. In making essays, students are required to follow predetermined rules. For example, the systematic writing of an essay should be gradual starting from the introduction to the list of references. Not only that, the language used in the essay must be precise and according to the purpose for which it is written.

\subsection{Writing Skill and The Implementation of Outlining Strategy}

Writing has always been regard an important skill contributing English learning (Sari D. M., 2019). In writing, the writer takes a long time to think in advance about what sentences to write. the length of time the author is different. There are some writers needing more time to think about what was written before make the initial draft. Writing means having to make a certain sequence of sentences and linking them together in a certain way. These sentences will form the usual paragraph consists of a main sentence as a topic and is followed by a series of supporting sentences main sentence. Therefore writing becomes a very complex and at that time cognitive activity sentence level, the writer must control the content, format, sentence structure, vocabulary, punctuation, and spelling (Flower, 1981).

Based on the theory above, it can be concluded that writing is a process 
that occurs over a period of time to generate a sequence of sentences arranged in a certain order and linked together in a certain way that is cohesive and coherent. In writing, there are several aspects that must be considered by the writer to obtain good writing that includes content, organization, word choice or vocabulary, language usage, and mechanics (spelling and punctuation) (Dwi Sulisworo, 2016).

The practitioner in foreign language education should find any possible solution in delivering the best teaching methods and strategies in teaching English as a foreign language (Sari D. M., 2016). Therefore, the writer needs a strategy in order to achieve the goal of writing well. One of the strategies that can be used is an outline. Preparing a written outline during prewriting and composing a rough 1st draft are strategies that may ease attentional overload and consequently enhance writing performance. The present research examined how these strategies affect the efficiency of the writing process and the quality of the written product. The processing time and cognitive effort given to planning ideas, translating ideas into text, and reviewing ideas and text were monitored by using directed retrospection and comparing secondarytask reaction times (Kellogg, 1988).

\section{RESEARCH METHOD}

\subsection{Research Design}

Research design is a series of research procedures carried out in detail to obtain information and collect data from a research. The research design function is to strengthen the evidence of the data obtained. Method research is a scientific way of obtaining data with a purpose specific uses (Darmadi, 2013). This research uses qualitative data.
Qualitative research is research that is used to investigate, find, describe, and explain the quality or features of social influences that cannot be explained, measured or described through a quantitative approach (Saryono, 2010). Qualitative research is an inquiry process of understanding based on distinct methodological traditions of inquiry that explores a social or human problem. The researcher builds a complex, holistic picture, analyzes words, report detailed views of information, and conducts the study in a natural setting (Herdiansyah, 2010).

\subsection{Participant and Criteria}

This study discusses using the outline strategy in learning essay writing from class 2019 A English language education students STKIP PGRI Sidoarjo.This data was taken at the STKIP PGRI Sidoarjo college where the researcher is also one of the students. The researcher observed the 2019 A essay writing class, which included to 10 students with 4 boys and 6 girls. There are two criteria for being a participant are first to follow and complete an essay writing class, especially on the outlining strategy material and the second one is willing to take the test through a questionnaire with fifteen yes-no questions that have been provided. This study focuses on the outline strategies that students apply in order to write well the essay writing.

\subsection{Data Collecting, Data Analysis Method and Instruments}

To obtain data, researchers used two data collection instruments namely checklist observation and questionnaires. According to (Arikunto, 2010), data collection instruments are tools that are selected and used by researchers in collecting data so that these activities become systematic and 
made easier by them. Steps to collect instrument data :

1. The first data collection is a observation checklist, the observation checklist is a data collection method in which the researcher provides evaluation information on the results of teacher performance and student learning activities in the classroom. This is done by researchers to determine learning activities in the classroom in order to further improve learning strategies and learning development. This observation checklist, the researcher directly observes the learning activities in the classroom to determine the implementation of the outline writing strategy in essay writing.

2. The next data collection for response assessment is the questionnaire. For the questionnaire given to students via google form which contains fifteen questions with the topic outline strategy. Students answer yes / no questions where the answers according to them match their abilities in the outline strategy.

\section{FINDING AND DISCUSSIONS}

This section will discuss the results of research in the classroom for an outline strategy in the form of data presented to inform the findings of the research that has been done. The illustration of the results of this study uses tables, diagrams and pictures. The results of this research instrument include questionnaires and observation checklists where the questionnaire form is for assessing student responses and the observation form for assessing implementation. Then the data will be presented and explained based on the questionnaire and observation checklist by checking the answer to the explanation yes or no as in the questionnaire before.

\subsection{Results From Observation Checklists Of The Respondents Data}

The first data to be discussed in classroom for an outlining strategy is a observation checklists. This data was taken from students of class 2019 A STKIP PGRI Sidoarjo English Language Education Program. This observation checklist is taken for three days every Monday on 4, 11 and 18 May 2020. The following shows a detailed table of student activities in class for 3 days and the application is always same every day between the first meeting, the second meeting and the third meeting

Table $1:$ Respondent's Data Based on Observation Checklists

\begin{tabular}{clcc}
\hline NO. & OBSERVATION OBJECTIVE & YES & NO \\
\hline a. & The class activities & \\
& A. Pre-teaching activities & $\checkmark$ \\
1. Lecturer and student greeting. & \\
2. Lecturer lead for pray together & $\checkmark$ \\
3. Checking all of student & attendant. \\
4. Explain today's lesson & $\checkmark$ \\
5. Motivates the students & to be active. & $\checkmark$ \\
& & $\checkmark$ \\
\hline
\end{tabular}


B. Whilst-teaching activities

1. Lecturer get the stimulus of the example of make an outline for make essay writing

2. Lecturer explain how to writing essay with outline

\section{Post-teaching activities}

1. The lecturer review and clarification about the material.

2. Lecturer reminds to prepare for the next meeting.

\section{b. The student activities}

\section{Pre-outlining activities}

1. The student respond the lecturer's greeting.

2. The student praying with the lecturer before starting class

3. The student respond the teacher's attendant check.

4. The student respond the lecturer's explanation.

5. The student are activated by the lecturer

6. The student respond the lecturer's brain storming

\section{E. Whilst outlining activities}

1. The students respond the stimulus from making outline

2. The student pay attention towards the lecturer's explanation.

3. The student make a group discussion:
a. The student cooperate and make a discussion with the other student.
b. The student participate actively.

4. The student understand how to make an outline to each group.

5. The student outlining of essay writing text correctly.

\section{F. Post-outlining activities}

1. The student listen and respond from outlining strategy explanation.

2. The student respond to the 
learning directions to make an outline

\subsection{Results from Respondent's Data Based on Questionnaire}

The second data to be discussed in the classroom for an outline strategy is a questionnaire. This data was taken from students of class 2019 A STKIP PGRI Sidoarjo English Language Education
Program. The researcher gave a questionnaire through Google Form consisting of fifteen questions that had to be filled in with yes or no answers. The following is a table containing the questions that students must fill in for data based on the questionnaire :

Table 2. Respondent's Data Based on a Google Form Questionnaire

\begin{tabular}{|c|c|c|c|}
\hline NO. & QUESTIONNAIRE & YES & NO \\
\hline 1. & I already understand the meaning of the outline & $100 \%$ & $0 \%$ \\
\hline 2. & I determine the topic in advance to make an outline & $100 \%$ & $0 \%$ \\
\hline 3. & I can arrange the outline well & $70 \%$ & $30 \%$ \\
\hline 4. & I know the function of making the outline & $100 \%$ & $0 \%$ \\
\hline 5. & I need to prepare an outline before writing an essay & $90 \%$ & $10 \%$ \\
\hline 6. & I have no difficulty in making an outline & $40 \%$ & $60 \%$ \\
\hline 7. & I make an outline for easy understanding & $100 \%$ & $0 \%$ \\
\hline 8. & $\begin{array}{l}\text { I first read each paragraph to find the main idea which is then } \\
\text { used as an outline }\end{array}$ & $100 \%$ & $0 \%$ \\
\hline 9. & $\begin{array}{l}\text { I feel that the outline can make writing clearer and more } \\
\text { focused }\end{array}$ & $80 \%$ & $20 \%$ \\
\hline 10. & I determine the main points to write into an outline & $100 \%$ & $0 \%$ \\
\hline 11. & I write an outline to shorten the time in writing an essay & $80 \%$ & $20 \%$ \\
\hline 12. & $\begin{array}{l}\text { I can arrange the opening and closing sentences of the essay by } \\
\text { looking at the outline }\end{array}$ & $90 \%$ & $10 \%$ \\
\hline 13. & I feel better when make an outline & $100 \%$ & $0 \%$ \\
\hline 14. & I can develop my writing by making an outline & $100 \%$ & $0 \%$ \\
\hline 15. & $\begin{array}{l}\text { I proofread all the outlines that I made when I finish writing } \\
\text { them }\end{array}$ & $100 \%$ & $0 \%$ \\
\hline \multicolumn{2}{|r|}{ TOTAL } & $90 \%$ & $10 \%$ \\
\hline
\end{tabular}

After the researcher calculates the above data using the percent formula. Then to find out the category of student score results during learning, researchers used the category table below :

Table 3. Learning Activity Assessment Category

\begin{tabular}{cc}
\hline Total Value & $\begin{array}{c}\text { Assessment of Learning } \\
\text { Activities }\end{array}$ \\
\hline $\mathbf{8 6 - 1 0 0}$ & Very good \\
$\mathbf{6 6}-85$ & Good \\
$46-65$ & Enough \\
$<45$ & Less \\
\hline
\end{tabular}

Source: (Arikunto S. , 2014) 
According to Arikunto's assessment table of learning activities above, it can be seen that based on the results of the questionnaire filled in by the participants with fifteen questions, it is known that the total result is $90 \%$, with these results it can be categorized as learning activities with an outlining strategy that goes very well in class, student responses are also many. which is positive, as evidenced by the percent results of the overall total in table 2 .

Based on the results in all table above, the following circle diagram of the respondent's description of the questionnaire implementation and student difficulties of learning essay writing using outlining strategy

Picture 1. Pie chart Student's responses of learning essay writing using outlining strategy

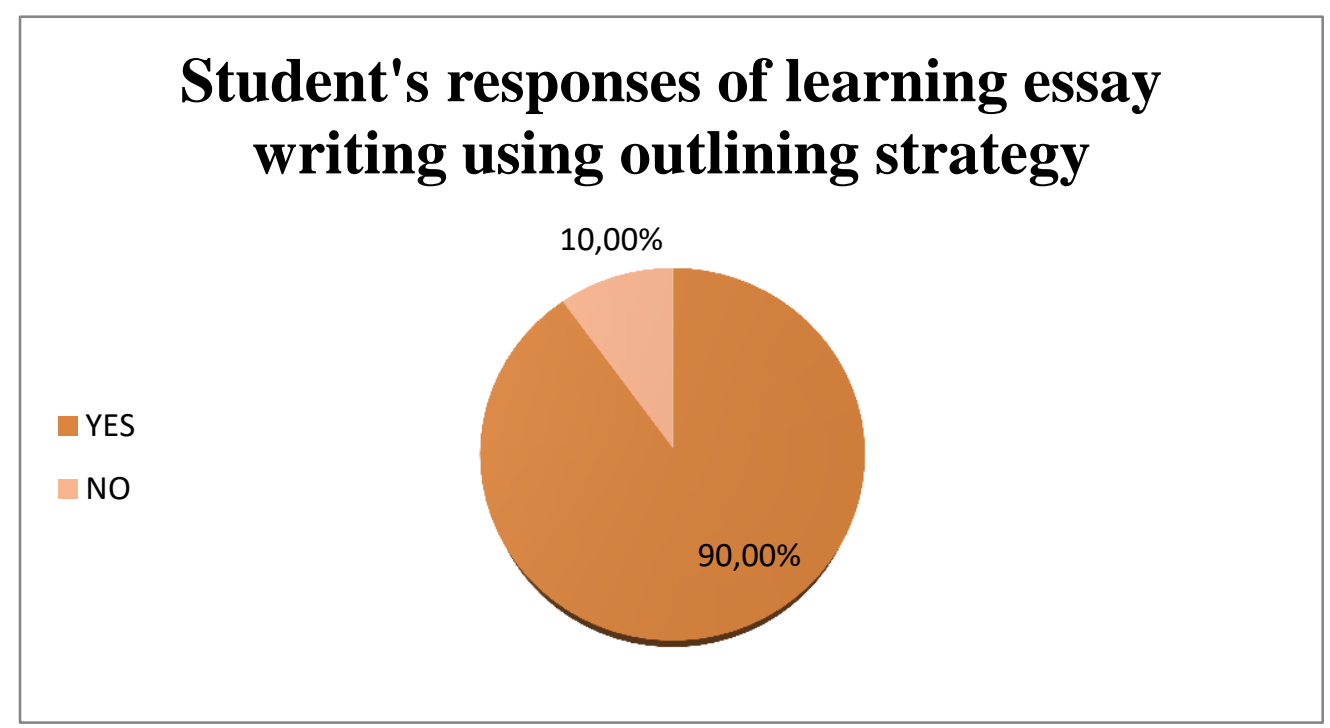

From on the data above, it can be seen that the classification of respondents based on the results of the questionnaire consists of answers to yes and no. $90 \%$ of respondents who answered yes occupied the dark orange circle. Meanwhile, $10 \%$ of respondents who answered no and occupied a light orange circle. $90 \%$ of data shows that students feel better using the outline before writing their essay because it is considered easier to understand essays. But the $10 \%$ data shows that some students still have difficulty when making their outlines.

Based on the observation checklists table 1. above it can be seen, the first thing to do is greetings, then pray together, attend student attendance, explaining the material and motivating all students to be active during learning activities. In whilst teaching activities exploration, ELT Students in outlining classroom activities get a stimulus of the example of make an outline for essay writing and the lecturer explain how to writing essay with outline. In post teaching activities, the lecturer review and clarification about the material and reminds to prepare for the next meeting.

All students pre outlining activities also respond to the lecturers 'greetings, pray together before starting learning, respond to the lecturer attendant check, respond to lecturers' explanations and are active during learning activities. students also do brain storming to collect ideas from each student during the lesson. Students really pay attention 
to the lecturer while explaining essay writing lessons, students are also asked to create groups to present outlining material. So they can learn the material easily and can exchange ideas with others.

Learning using an outline strategy can make students better understand about making outline of an essay to understanding and shorten time in essay writing because the outline only includes point of each paragraph of the essay. They can also build critical thinking and can solve difficulties in outlining text. During the learning activities the lecturer also trains ELT students well, so that they can make outlines for writing essays.

For the questionnaire table 2. shows that all students (Yes $=100 \%$, No $=$ $0 \%$ ) in this study are already understand the meaning of the outline. Before making an outline, all students (Yes = $100 \%$, No $=0 \%$ ) agreed to determine the topic first. Most of the students (Yes $=70 \%, \mathrm{No}=30 \%$ ) also can arrange the outline well. All students (Yes $=100 \%$, No $=0 \%$ ) also know the function should make outline first. Before writing essay, most of the students (Yes $=90 \%$, No $=10 \%$ ) need to prepare an outline. Although all students know the function of the outline, not a few students (Yes $=40 \%$, No $=60 \%$ ) are still having difficulty making an outline. All students (Yes $=100 \%$, No $=0 \%$ ) only can make an outline for easy understanding. Students (Yes $=100 \%$, No $=0 \%$ ) also read each paragraph to find the main idea which is then used as an outline. By making an outline, essay who will made by students (Yes $=80 \%$, No $=20 \%$ ) will be clearer and focused. Before all students write an outline, they $($ Yes $=100 \%$, No $=0 \%)$ must determine the main points, so that most of the students (Yes $=80 \%$, No $=20 \%$ ) have short time to write an essay.
Students (Yes $=90 \%$, No, $=10 \%)$ also can arrange the opening and closing sentences of the essay. All students (Yes $=100 \%$, No $=0 \%)$ feel better when make an outline so that they (Yes $=100 \%$, No $=0 \%$ ) can develop their essay writing. After all students finish writing an outline, they (Yes $=100 \%$, No $=0 \%$ ) proofread all the outlines.

From the all explanation above, it can be concluded that implementing outline writing before writing an essay in class 2019 A English language education STKIP PGRI Sidoarjo is the most effective way of how students must first arrange their ideas, so that they are systematically arranged when the essay they have written has been completed. If the outline made is in accordance with the direction given by the lecturer, then the outline will be suitable to be developed into a real essay.

\section{CONCLUSION}

Based on all the descriptions above, the researcher concluded that writing is one of the most important skills in English that must be learned and mastered especially for an ELT students. Writing is a great way to gain insight. By writing, students can increase penchant for reading various literature to enrich word terms and add material to your conversation in written form. As an ELT student, must required to master these writing skills in order to be able to write essays well. But may some students when they are writing, they become unfocused on what their will write, so that the content of their essay writing is not focused, to overcome that it is necessary to make an outline strategy before writing an essay.

The researcher has been discussed the research focus of this article, which is about the strategy outline for ELT students for essay writing. Researchers 
have conducted an observation checklist and distributed questionnaires to be filled out by respondents. The results of this study indicate that there are still some ELT students who have difficulty writing essays based on questions from the questionnaire. For this reason, the strategy of writing an outline must first be done before writing an essay, so that the writing becomes more focused, not far from the topic of discussion and makes writing easier. Many ELT students responded positively and very good through learning to apply the outline strategy in writing essays based on the results of the quistionnaire and the researcher's checklist observation experience in essay writing classroom. From the conclusion of the description above, it can be said that the use of the strategy of writing an outline before writing an essay was successfully implemented in the 2019 A English language education class at STKIP PGRI Sidoarjo because this is a good strategy and makes it easier for students to write essays, so that writing essays is not far from the topic of discussion.

\section{REFERENCES}

Abhijit, C. S. (2012). Insights and Innovations in Teaching ESL for Rural Students-A Case Study. Language in India , 12 (2), 35-45. Retrieved from http://www.languageinindia.com/feb 2012/abhijitruralenglishfinal.pdf.

Ahmed, A. H. (2010). Students' problems with cohesion and coherence in EFL essay writing in Egypt: Different perspectives. Literacy Information and Computer Education Journal (LICEJ) , 1(4), 211-221. Retrieved from https://infonomicssociety.org/wp-

content/uploads/licej/publishedpapers/volume-1-2010/StudentsProblems-with-Cohesion-andCoherence-in-EFL-Essay-Writing-inEgypt-Different-Perspectives.pdf
Akinwamide, T. K. (2012). The Influence of Process Approach on English as Second Language Students' Performances in Essay Writing. English Language Teaching , 5(3), 16-29. Retrieved from http://www.ccsenet.org/journal/index .php/elt/article/view/15263

Amatul Firdausah, D. M. (2020). Project Based Learning on EFL Student's in Essay Writing. Jurnal Ilmiah Wahana Pendidikan , 6(4), 841-848. Retrieved from https://jurnal.unibrah.ac.id/index.php/ JIWP/article/view/514.

Arikunto, S. (2014). Penelitian Tindakan Kelas. Jakarta: PT Bumi Aksara.

Arikunto, S. (2010). Prosedur Penelitian Suatu Pendekatan Praktik. Yogyakarta: Rineka Cipta.

Ayu Windyawati Puspita Wardani, D. M. (2020). Students' Attitude in Reading Classroom. Jurnal Ilmiah Wahana Pendidikan, 6(4), 849-854. Retrieved from

https://jurnal.unibrah.ac.id/index.php/ JIWP/article/view/483.

Creswell, J. W. (2017). Research design: qualitative, quantitative, and mixed methods approaches.

Dalman. (2015). Menulis Karya Ilmiah. Jakarta: Rajawali Pers.

Darmadi, H. (2013). Metode penelitian pendidikan dan sosial. Bandung: Alfabeta.

Dwi Sulisworo, T. R. (2016). The Students' Academic Writing Skill After Implementing Blended Learning Using Facebook. Information Technologies and Learning Tools, 56 (6), 178. Retrieved from https://journal.iitta.gov.ua/index.php/ ittl/article/view/1477.

Flower, L. \&. (1981). A cognitive process theory of writing. College composition and communication, 32 (4), 365-387.

Garcia-Esteban, S. \&. (2020). Skills in European higher education mobility programmes: outlining a conceptual framework. Higher Education, Skills and Work-Based Learning . 
Herdiansyah, H. (2010). Metodologi Penelitian Kualitatif untuk Ilmu-Ilmu Sosial. Jakarta: Salemba Humanika.

Jabbarova, A. (2020). The System Of Exercises For Teaching Essay Writing In English, Applied Science of Higher Education. Архив Научных Публикаиий JSPI .

Jamroni, M. (2015). The effect of using free writing technique toward Writing Achievement of the tenth year students of junior High School. E Journal UPS tegal , 8-32. Retrieved from http://ejournal.upstegal.ac.id/index.php/Cakr awala/article/view/322/320.

Kellogg, R. T. (1988). Attentional overload and writing performance: Effects of rough draft and outline strategies. Journal of Experimental Psychology: Learning, Memory, and Cognition, 14 (2), 355-365. Retrieved from https://www.researchgate.net/publica tion/26605689_Training_writing_skil 1s_A_cognitive_development_perspe ctive

Michella Sandra Arizena, D. M. (2021). PARAPHRASING STRATEGY IN EFL LEARNERS'READING SKILL. Magister Scientiae , 49 (1), 66-76. doi https://doi.org/10.33508/mgs.v49i1.3 099

Muhammad Farras Rasyad, D. M. (2020). Students' Difficulties of Essay Writing on Virtual Learning. JURNAL ILMIAH WAHANA PENDIDIKAN , 6(4), 867-871. doi : https://doi.org/10.5281/zenodo.430933

Nurhadi. (2017). Handbook of Writing (Panduan Lengkap Menulis). Jakarta: Bumi Aksara.

Onwuegbuzie, A. J. (2012). Introduction: Putting the MIXED back into quantitative and qualitative research in educational research and beyond: Moving toward the radical middle. International Journal of Multiple Research Approaches , 6 (3), 192219.

Prat-Sala, M. \&. (2012). Writing essays: Does self-efficacy matter? The relationship between self-efficacy in reading and in writing and undergraduate students' performance in essay writing. Educational Psychology, 32(1), 9-20.

Redman, P. \&. (2017). Good essay writing: a social sciences guide. Sage.

Rojas, V. (2010). Language features of seven writing genres. Education Consultant (732).

Sargeant, J. (2012). Qualitative Research Part II: Participants, Analysis, and Quality Assurance. Journal of graduate medical education, 4(1), 13.

Sari, D. M. (2019). An Error Analysis on Students' Translation Text. Eralingua , 3 (2), 65-74

Sari, D. M. (2019). An Overview of Genre Based Approach in Efl Writing Class. Journal of English Education , 1 (1), 31-40.

Sari, D. M. (2019). The Effectiveness of Corrective Feedback to The Students' Grammatical Construction on Paragraph Writing Class. Journal of English Educational Study, 2 (2), 122-131. Retrieved from http://jurnal.stkippersada.ac.id/jurnal/ index.php/JEES/article/view/520

Sari, D. M. (2016). The Use of Skimming and Scanning Techniques to Improve. Edukasi , 2 (1), 59-68.

Saryono, A. (2010). Metodologi Penelitian Kualitatif dalam Bidang Kesehatan. Yogyakarta: Nuha Medika.

Silverman, D. (2013). Doing qualitative research: A practical handbook. Sage.

Siti Frastiwi, D. M. Teaching Essay Writing To The ELT Students'. Jurnal Ilmiah Wahana Pendidikan, 6(4), 835-840.

Toba, R. N. (2019). The Current Issues of Indonesian EFL Students' Writing Skills: Ability, Problem, and Reason in Writing Comparison and Contrast Essay. Dinamika Ilmu , 19 (1), 57-73. 
Urrutia L. J, \&. G. (2011). Adolescents' Awareness of Environmental Care: Experience when Writing Short Descriptive Texts in English. Profile Issues in Teachers' Professional , 13, 11-30.

Wijayanti, S. H. (2011). Dari EYD ke Esai: Dilengkapi Soal-Jawab. Ed. Ke-2. Jakarta: Universitas Atma Jaya Jakarta.

Winardi, Y. K. (2020). Improving Students'writing Skill Using A Mobile Learning Application. Jurnal Basis , 7 (20), 281-290. doi : https://doi.org/10.33884/basisupb.v7i2. $\underline{2433}$

Woods-Groves, S. H. (2012). Effectiveness of an essay writing strategy for postsecondary students with developmental disabilities. Education and Training in Autism and Developmental Disabilities, 210-222. , 210-222. 